\title{
Factors Related to Quality of Life among Elderly During COVID-19 Pandemic
}

\section{Maulidiya Fadila ${ }^{1}$, Diah Argarini ${ }^{2}$, Susanti Widiastuti ${ }^{2}$}

${ }^{1}$ Student Program Study of Nursing, Faculty of Health Sciences, Nasional University

${ }^{2}$ Lecture Program Study of Nursing, Faculty of Health Sciences, Nasional University

\begin{tabular}{l}
\hline \multicolumn{1}{c}{ Article information } \\
\hline Article history: \\
Received: January 09th, 2022 \\
Revised: January 16th, 2022 \\
Accepted: February 15th, 2022 \\
\\
\hline \\
Corresponding author: \\
Diah Argarini \\
Faculty of Health Sciences, Nasional \\
University. Jalan Harsono RM, \\
Ragunan, South Jakarta \\
E-mail: \\
diah.argarini@civitas.unas.ac.id
\end{tabular}

International Journal of Nursing and Health Services (IJNHS)

Volume 5, Issue 1, February 20th, 2022

http:// doi.org/10.35654/ijnhs.v5i1.567

E-ISSN: 2654-6310

\begin{abstract}
Introduction: The elderly are one of the age groups most affected by COVID-19, with the highest percentage of deaths due to COVID-19. Several studies have shown that during the COVID-19 pandemic, the elderly experienced a decrease in their physical and psychological health level, which could lead to changes in the quality of life among the elderly COVID-19 pandemic. Objective: The study aimed to identify factors related to the quality of life among the elderly at the Tresna Werdha Budi Mulia 3 Nursing Home during the COVID-19 pandemic. Method: This study used a cross-sectional approach. The population is elderly without mental disorders living in the Tresna Werdha Budi Mulia 3 Nursing Home. A total of 88 samples were selected using the purposive sampling technique. The instruments used are QOL-Index, WHOQOL-BREF, and DSES questionnaires. Pearson Chi-Square analysis was used to identify the relationship between variables. Result: The results showed that the five factors were physical health $(p=0.000)$, psychological health $(p=0.000)$, social relationships $(p=0.000)$, environmental $(p=0.000)$, and spirituality $(p=0.000)$ had a significant relationship with the quality of life among the elderly. Recommendation: It is hoped that the results of this study can be used as motivation for nursing home administrators and the elderly to improve the quality of life during the COVID-19 pandemic onwards.
\end{abstract}

Keywords: quality of life, elderly, COVID-19 pandemic.

This is an Open Access article distributed under the terms of the Creative Commons Attribution 4.0 International License CC BY $-4.0$ 


\section{INTRODUCTION}

Starting at the beginning of 2020 until now, the world, including Indonesia, was shocked by an outbreak that was quite extraordinary. The outbreak is the COVID-19 pandemic, where this outbreak began with the discovery of cases in Wuhan, China, to spread throughout the world. The COVID-19 pandemic has had many negative impacts in various aspects, from health to economic factors. Until now, COVID-19 has spread to all parts of the world with a considerable number, especially in elderly cases.

As of July 7th, 2021, according to Worldometer's COVID-19 data, there have been $185,895,148$ cases with 4,018,931 deaths and $170,131,616$ cures worldwide (1). According to information collected by the Indonesian COVID-19 Task Force, there have been 2,379,397 cases in Indonesia alone, with 343,101 active cases, 1,973,388 recoveries, and 62,309 deaths. DKI Jakarta is one of the most significant contributors, with $25.6 \%$ of cases from Indonesia, namely 610,293 cases, with 100,120 active cases, 501,177 recoveries, and 8,996 deaths. Based on age group, the percentage of older people affected by COVID19 in Indonesia is $11.2 \%$ confirmed positive, $10.2 \%$ elderly who are treated or isolated, $10.1 \%$ of the elderly have recovered, and $49.6 \%$ died (2). Although the number of patients who were confirmed positive and treated or isolated was not too high for the elderly group, the number of deaths was the highest compared to other age groups, exceeding $49.6 \%$. This is caused by declining health conditions and congenital diseases in the elderly.

Based on data from Riskesdas (Basic Health Research) in 2018 (3), it was reported that most older people tend to suffer from noncommunicable diseases such as stroke, heart disease, diabetes, pneumonia, and well as hypertension when compared to the younger generation. The research results by Raden Muhammad Ali Satria et al., 2020 (4) suggest that high blood pressure, diabetes, and cardiovascular disease are comorbid risk factors for death in COVID-19. Based on the results of the association between the diseases experienced by the elderly and the comorbid COVID-19 disease, the elderly were declared the group most affected by the COVID-19 pandemic. The elderly have a high enough vulnerability to COVID-19. Although all age groups are at risk of contracting it, older people are at significant risk of developing a disease with more severe symptoms when infected because of the physiological changes accompanying aging and the potential for underlying health conditions.

Several previous studies have suggested the impact of the COVID-19 pandemic on the elderly. Based on the results of research by Osuke Komazawa et al., 2020 (5) with the research topic "Elderly and COVID-19 in Indonesia," which has elderly respondents who come from data in the SILANI (Elderly Information System) project with a total of 3,430 respondents in Indonesia, stated that $16.80 \%$ of respondents said their health condition declined. Around 25\% experienced an increase in depression during the COVID-19 pandemic. Then regarding social interaction, $4.9 \%$ of respondents have never interacted socially at all, and $53 \%$ of respondents interacted via telephone calls. In addition, according to the results of research conducted by Guslinda et al., 2020 (6) at the Tresna Werdha Sabai Nan Aluih Sicincin Social Institution, Padang Pariaman Regency, with a total of 110 respondents (aged $60-98$ years), stated that $70 \%$ of respondents experienced mild anxiety with the presence of The COVID-19 pandemic.

According to the World Health Organization (2012) (7), the definition of Quality of Life or Quality of Life is the perception of individuals in their lives. The cultural context, attitudes, and value systems in which they live are related to living standards, expectations, pleasures, and individual evaluations of their position in the world. Life. Based on the results of research by Indah Mulya et al., 2021 (8), it was found that factors that influence the quality of life among the elderly include family support, peer support, living environment, physical health, psychological health, health services, marital status, education, and spirituality. Based on the results of research by Karen M. van Leeuwen et al. (2019) (9) found that there are nine aspects of quality of life in the elderly, including autonomy, roles and activities, health perceptions, relationships, attitudes and adaptation, emotional comfort, spirituality, 
home and environment, and financial security. According to WHO Quality of Life (2012) (7), there are four domains of quality of life for the elderly: physical health, psychological health, social relationships, and environmental aspects. Some of these research results show that there are several dominant factors affecting the quality of life among the elderly, including elements of physical health, psychological health, social relations, environment, and spirituality.

Based on the research results by Shiny Easter Yanti et al. (2019) (10), there is a comparison of the quality or quality of life between the elderly living at home and the elderly living in the nursing home. The difference in the environment between elderly who live in the home. The elderly living with their families is caused by the elderly living in the nursing home having less time to meet and gather with their families. The reduced time to meet with family can cause the elderly to feel that they do not get happiness from their families.

A nursing home is one of the health services for the elderly that provides the same health and social services like housing, treatment rooms, and other service facilities. A nursing home is a special place for the elderly, usually found in urban areas. The city of Jakarta is the capital city of the country and the center of the country's economy. Its people have a relatively high level of activity or activity. This increased activity level in the productive age community can result in a lack of time to be with the elderly or parents at home, so many older people in Jakarta choose to live in nursing homes. One of the nursing homes in Jakarta is the Tresna Werdha Budi Mulia 3 Nursing Home, South Jakarta.

Tresna Werdha Budi Mulia 3 Nursing Home South Jakarta is a Technical Implementation Unit for the Elderly Welfare Division of the DKI Jakarta Provincial Social Service as a service and information institution for the community. Tresna Werdha Budi Mulia 3 Nursing Home was established in 1965 with the initial name Tresna Werdha Budi Mulia 4 Nursing Home, later changed to Tresna Werdha Budi Mulia 3 Nursing Home in 2014. Tresna Werdha Budi Mulia 3 Nursing Home is Margaguna Street, South Gandaria, Cilandak, Postal Code 12420. Tresna Werdha Budi Mulia
3 Nursing Home has a capacity of 350 Elderly Social Assisted Citizens (11).

During the COVID-19 pandemic, there were several changes in living habits at Tresna Werdha Budi Mulia 3 Nursing Home, South Jakarta, including reduced physical activity and social activities organized by the nursing home. The occurrence of these conditions will affect the quality of life among the elderly during the COVID-19 Pandemic at Tresna Werdha Budi Mulia 3 Nursing Home, South Jakarta.

Maintaining the quality of life in the elderly is very important because every elderly must expect old age with a good quality of life to carve out beautiful moments at the end of their life. The decline of quality of life among the elderly during the COVID-19 pandemic can invalidate the hopes or desires of such older people. Therefore, it is necessary to handle the decline in the quality of life among the elderly during the COVID-19 pandemic, namely by knowing in advance what factors are related to the quality of life among the elderly during the COVID-19 pandemic.

\section{OBJECTIVE}

The study aimed to identify factors related to the quality of life among the elderly during the COVID-19 pandemic at the Tresna Werdha Budi Mulia 3 Nursing Home.

\section{METHODS \\ Design}

A cross-sectional study was applied to examine the relationship between physical, psychological, social, environmental, and spirituality factors with the quality of life among the elderly during the COVID-19 pandemic.

\section{Sample size and sampling technique}

The population in this study were older people without mental disorders who lived in the Tresna Werdha Budi Mulia 3 Nursing Home, totaling 113 older people. The sampling technique used is the purposive sampling technique. The sample size was calculated using the Slovin formula (12) with a sample of 88 respondents. The inclusion criteria: 1) Respondents aged 60 years or older, 2) Respondents are elderly who live permanently at the Tresna Werdha Budi Mulia 3 Nursing Home, 3) Elderly who are willing to become 
respondents; as well as exclusion criteria: 1) non-potential elderly who can no longer communicate, 2) elderly who are sick or being treated.

\section{The instrument for data collection}

The instruments used in this study are 1) Quality of Life Index Questionnaire. This questionnaire is an instrument developed by Ferrans and Powers to measure the overall quality of life in terms of life satisfaction (13). The QOL-Index instrument was retested in this study because it translated and modified some of the questions. The results of the r-count validity test are $0.52-0.88$, and the reliability test results are Cronbach's Alpha 0.97, so this instrument can be said to be valid and reliable.

2) The WHOQOL-BREF (World Health Organization Quality of Life-BREF) questionnaire, this instrument is a development of the WHO QOL-100 instrument. This instrument was created by the WHO's quality of life team (14). The WHOQOL-BREF instrument has 26 questions. According to Raudhah (2012) in (Koesmanto, 2013) (15) said that to assess the WHOQOL-BREF, four domains are combined, namely the physical, psychological, social relations, and environmental domains. All questions are based on a five-point Likert scale (1-5). This instrument is a standard instrument validated with the results of $r=0.89-0.95$ and is reliable with a Cronbach's Alpha value of 0.87 , and an Indonesian version is available.

3) Daily Spiritual Emotional Scale (DSES) questionnaire is an instrument developed by Underwood and Teresi (16) as a standard instrument to measure an individual's spiritual experience towards God. This standard questionnaire is valid with a calculated r-value of $0.36-0.83$ and is reliable with a Cronbach's Alpha value of 0.95. The DSES questionnaire consists of several indicators, including relationships, joy with God, perceptions of love with God, feelings of admiration, feelings of gratitude, caring, unity, and close relationships.

\section{Data collection process}

Data collection was carried out at Tresna Werdha Budi Mulia 3 Nursing Home, South Jakarta City, DKI Jakarta, on November $24^{\text {th }}-$ $28^{\text {th }}, 2021$. The data collection was started by first obtaining a research permit from the DKI Jakarta Province Social Service. After getting permission, the researcher took a sample and informed consent to become a respondent. Data collection was done by interviewing respondents one by one using a questionnaire sheet.

\section{Data analysis}

The univariate analysis variables in this study included data describing the characteristics of the respondents in the form of gender and age, the level of quality of life among the elderly, the level of physical health, the level of psychological health, the level of social relations, the level of environmental, and the level of the spirituality among elderly. In the bivariate analysis, the data was analyzed to find out that there was a significant relationship between one variable and another, namely the relationship between physical health and the quality of life among the elderly during the COVID-19 pandemic. The relationship between psychological health and the quality of life among the elderly during the COVID-19 pandemic. The relationship between social relations with the quality of life among the elderly during the COVID-19 pandemic, the relationship between the level of environmental security, and the quality of life among the elderly during the COVID-19 pandemic. The relationship between spirituality and the quality of life among the elderly during the COVID-19 pandemic.

The data analysis used the Chi-Square test with the help of the SPSS application on the computer. Chi-Square analysis was used to test the comparative hypothesis. In deciding whether there is a relationship between the dependent and independent variables, the $\mathrm{p}$ value is used, compared with the error rate or alpha of $5 \%$ or 0.05 . If p-value $<0.05, \mathrm{H} 0$ is rejected, and $\mathrm{H} 1$ fails to be rejected (accepted). It was indicated that there is a relationship between the dependent and independent variables. If $p$-value $>0.05$, Ho fails to be rejected (accepted), and H1 is rejected, which means there is no relationship between the dependent and independent variables.

\section{RESULTS}


Table 1 shows that of the 88 respondents, the most dominant gender characteristics, as much as $54.5 \%$ are women, while based on the age of the respondents, the most are aged $60-70$ years with a total of 54 respondents $(61.4 \%)$.

Tabel 1. Respondent Characteristics Frequency

\begin{tabular}{lcc}
\hline Characteristic & Frequency & Presentence \\
\hline Gender & & \\
Male & 40 & 45.5 \\
Female & 48 & 54.5 \\
\hline Total & 88 & 100 \\
\hline Age & & \\
$60-70$ yo & 54 & 61.4 \\
$71-81$ yo & 25 & 28.4 \\
$>80$ yo & 9 & 10.2 \\
\hline Total & 88 & 100 \\
\hline
\end{tabular}

Table 2 shows the study results that most of the elderly respondents at the Tresna Werdha Budi Mulia 3 Nursing Home have a low level of quality of life, as many as 48 respondents $(54.5 \%)$. The section on physical health results shows that of the four categories of physical health, the most dominant experienced by respondents is physical health, with a fairly good category as many as 43 respondents (48.9\%). The psychological health section shows that the level of psychological health experienced by most respondents is the level of psychological health that is less stable with 42 respondents (47.7\%).

In the social relations section, it is known that respondents in Tresna Werdha Budi Mulia 3 Nursing Home during the COVID-19 pandemic dominantly had less active social relationships, with a total of 54 respondents (61.4\%). The environmental section showed that the highest percentage of respondents' answers related to their living environment was an environment with an inadequate category, namely 51 respondents $(58 \%)$. And on the spiritual side, the results show that most of the respondents have a poor spiritual level compared to those with an excellent spiritual level. Respondents with poor spirituality level were 51 respondents (58\%).

Tabel 2. Univariate Variables Frequency.

In table 3 , the physical health section shows that most of the respondents with low quality of life have poor physical health levels, as many as 29 respondents (33\%). In moderate quality of life, most respondents have a fairly good level of physical health, namely as many as 24 respondents $(27.3 \%)$. In high quality of life, there are only 2 respondents, where the 2 respondents have a good level of physical health. The results of the Pearson Chi-Square test have a relationship between the level of physical health and the quality of life among the elderly. There is a $p$-Value $=0.000$, which means that the physical health factor with the quality of life among the elderly has a significant relationship

\begin{tabular}{lcc}
\hline Variable & Frequency & Presentence \\
\hline 1. Quality Of Life & & \\
Low & 48 & 54.5 \\
Moderate & 38 & 43.2 \\
High & 2 & 2.3 \\
\hline Total & 88 & 100 \\
\hline 2. Physical Health & & \\
Not Good & 33 & 37.5 \\
Fairly Good & 43 & 48.9 \\
Good & 11 & 12.5 \\
Very good & 1 & 1.1 \\
\hline Total & 88 & 100 \\
\hline 3. Psychological & & \\
Health & & \\
Less Stable & 42 & 47.7 \\
Quite Stable & 37 & 42.0 \\
Stable & 7 & 8.0 \\
Very Stable & 2 & 2.3 \\
\hline Total & 88 & 100 \\
\hline 4. Social Relation & & \\
Less Active & 54 & 61.4 \\
Quite Active & 32 & 36.4 \\
Active & 2 & 2.3 \\
Very Active & 0 & 0 \\
\hline Total & 88 & 100 \\
\hline 5. Environment & & \\
Inadequate & 51 & 58.0 \\
Adequate Enough & 36 & 40.9 \\
Adequate & 1 & 1.1 \\
Very Adequate & 0 & 0 \\
\hline Total & 88 & 100 \\
\hline 6. Spiritual & & \\
Poor & 51 & 58.0 \\
Good & 37 & 42.0 \\
\hline Total & 88 & 100 \\
\hline & & \\
\hline & & \\
\hline & & \\
\hline & & \\
\hline
\end{tabular}


Tabel 3. Bivariate Test Result

\begin{tabular}{|c|c|c|c|c|c|c|c|c|c|}
\hline \multirow[t]{3}{*}{ Variable } & \multicolumn{6}{|c|}{ Quality Of Life Of Elderly } & \multirow{2}{*}{\multicolumn{2}{|c|}{ Total }} & \multirow{3}{*}{$\begin{array}{l}\mathrm{P} \\
\text { Value }\end{array}$} \\
\hline & \multicolumn{2}{|c|}{ Low } & \multicolumn{2}{|c|}{ Moderate } & \multicolumn{2}{|c|}{ High } & & & \\
\hline & $\mathrm{N}$ & $\%$ & $\mathrm{~N}$ & $\%$ & $\mathrm{~N}$ & $\%$ & $\mathrm{~N}$ & $\%$ & \\
\hline \multicolumn{10}{|l|}{ Physical Health } \\
\hline Poor & 29 & 33 & 4 & 4.5 & 0 & 0 & 33 & 37.5 & \\
\hline Fairly Good & 19 & 21.6 & 24 & 27.3 & 0 & 0 & 43 & 48.9 & 0.000 \\
\hline Good & 0 & 0 & 9 & 10.2 & 2 & 2.3 & 11 & 12.5 & \\
\hline Very good & 0 & 0 & 1 & 1.1 & 0 & 0 & 1 & 1.1 & \\
\hline Total & 48 & 54.5 & 38 & 43.2 & 2 & 2.3 & 88 & 100 & \\
\hline \multicolumn{10}{|c|}{ Psychological Health } \\
\hline Less Stable & 37 & 42 & 5 & 5.7 & 0 & 0 & 42 & 47.7 & \\
\hline Quite Stable & 11 & 12.5 & 26 & 29.5 & 0 & 0 & 37 & 42 & 0.000 \\
\hline Stable & 0 & 0 & 6 & 6.8 & 1 & 1.1 & 7 & 8 & \\
\hline Very Stable & 0 & 0 & 1 & 1.1 & 1 & 1.1 & 2 & 2.3 & \\
\hline Total & 48 & 54.5 & 38 & 43.2 & 2 & 2.3 & 88 & 100 & \\
\hline \multicolumn{10}{|l|}{ Social Relation } \\
\hline Less Active & 43 & 48.9 & 11 & 12.5 & 0 & 0 & 54 & 61.4 & \\
\hline Quite Active & 5 & 5.7 & 26 & 29.5 & 1 & 1.1 & 32 & 36.4 & 0.000 \\
\hline Active & 0 & 0 & 1 & 1.1 & 1 & 1.1 & 2 & 2.3 & \\
\hline Very Active & 0 & 0 & 0 & 0 & 0 & 0 & 0 & 0 & \\
\hline Total & 48 & 54.5 & 38 & 43.2 & 2 & 2.3 & 88 & 100 & \\
\hline \multicolumn{10}{|l|}{ Environment } \\
\hline Inadequate & 44 & 50 & 7 & 8 & 0 & 0 & 51 & 58 & \\
\hline Adequate Enough & 4 & 4.5 & 30 & 34.1 & 2 & 2.3 & 36 & 40.9 & 0.000 \\
\hline Adequate & 0 & 0 & 1 & 1.1 & 0 & 0 & 1 & 1.1 & \\
\hline Very Adequate & 0 & 0 & 0 & 0 & 0 & 0 & 0 & 0 & \\
\hline Total & 48 & 54.5 & 38 & 43.2 & 2 & 2.3 & 88 & 100 & \\
\hline \multicolumn{10}{|l|}{ Spiritual } \\
\hline Poor & 39 & 44.3 & 12 & 13.6 & 0 & 0 & 51 & 58 & 0.000 \\
\hline High & 9 & 10.2 & 26 & 29.5 & 2 & 2.3 & 37 & 42 & \\
\hline Total & 48 & 54.5 & 38 & 43.2 & 2 & 2.3 & 88 & 100 & \\
\hline
\end{tabular}

The psychological health section shows that respondents with the most dominant low quality of life have a less stable level of psychological health, as many as 37 respondents (42\%). In moderate quality of life, most respondents have a fairly stable level of psychological health, namely 26 respondents $(29.5 \%)$. In high quality of life, there is 1 respondent has a stable level of psychological health and one respondent with very stable psychological health. Pearson Chi-Square results from the relationship between the level of psychological health with the quality of life among elderly there is a $\mathrm{p}$-Value $=0.000$, which means that the psychological health factor with the quality of life among elderly has a significant relationship.

The social relations section showed that the proportion of respondents with low quality of life most dominantly had less active social relationships with 43 respondents (48\%).

In moderate quality of life, most respondents mostly have quite active social relationships with 26 respondents (29.5\%). There are two respondents in high quality of life, where one respondent has quite active social relations and one respondent with active social relations. Pearson Chi-Square results from the relationship between social relationship status and quality of life among 
elderly there is a $\mathrm{p}$-Value $=0.000$, which means that the social relationship factor with the quality of life among elderly has a significant relationship.

The environmental section showed that the proportion of respondents with low quality of life most dominantly had inadequate environmental conditions, with 44 respondents (50\%). Most respondents with moderate quality of life had adequate environmental conditions, as many as 30 respondents (34.1\%). Likewise, both respondents have sufficient environmental conditions with respondents with a high quality of life. Pearson Chi-Square results from the relationship between environmental conditions and the quality of life among elderly there is a $\mathrm{p}$-Value $=0.000$, which means that environmental factors with the quality of life among elderly have a significant relationship.

The spirituality section shows that the proportion of respondents with low quality of life most dominantly has a poor spirituality level, as many as 39 respondents (44.3\%). Respondents with moderate quality of life have the highest level of spirituality. Likewise, respondents with a high quality of life all have a good level of spirituality. Pearson Chi-Square results from the relationship between spiritual level and the quality of life among elderly there is a p-Value of 0.000 , which means that the spirituality factor with the quality of life among elderly has a significant relationship.

\section{DISCUSSION}

\section{Relationship of Physical Health Factors with Quality of Life among the Elderly.}

Based on the analysis conducted with the Pearson Chi-Square test, the results obtained $\mathrm{p}$-Value $=0.000$. This shows a significant relationship between physical health factors and the quality of life among the elderly during the COVID-19 pandemic at the Tresna Werdha Budi Mulia 3 Nursing Home.

According to Ferretti et al. (2018) (17), various declines in physical conditions in the elderly can determine their quality of life. This will hinder their daily activities or social environment and interfere with their mental health. Deteriorating and aging physical conditions make the elderly feel that their life is no longer meaningful and despairing of their current life.

The results of this study are in line with research by Anis Ika et al. (2012) (18), wherein his research some results relate physical health factors to the quality of life among the elderly, with $\mathrm{p}$-Value $=0.000$. In his study, most older people at the Hargo Denali Nursing Home have poor physical health. Poor physical health factors will make a person lose the opportunity to actualize himself because of his physical limitations. These physical limitations can hinder the achievement of physical well-being, which will impact a low quality of life.

This study is also in line with a previous study (19) where the researchers found that most of the elderly answered that they were not satisfied with their physical health. This is because the pain or pain they feel cannot affect the elderly to carry out various activities or work. According to Osuke Komazawa et al., 2020 (5) stated that $16.80 \%$ of the 3,430 elderly respondents in Indonesia said their health condition had decreased, and about $25 \%$ experienced an increase in depression during the COVID-19 pandemic.

Based on several theories and research above, it can be concluded that physical health conditions have an essential role in the quality of life among the elderly. When the physical health of the elderly is in poor condition, it will cause various other problems such as increased stress, decreased social relations, and reduced spirituality due to physical limitations for worship, which can lead to low quality of life. Likewise, with respondents at the Tresna Werdha Budi Mulia 3 Nursing Home, more than $50 \%$ of respondents answered that they were not satisfied with their physical health condition, especially during the COVID-19 pandemic. Their physical health began to decline due to impaired immunity and limitations in carrying out physical activities and some activities during the COVID-19 pandemic.

\section{Relationship of Psychological Health Factors with Quality of Life among Elderly}

The analysis results carried out with the Pearson Chi-Square test obtained $\mathrm{p}$-Value $=$ 0.000 . This shows a significant relationship between psychological health factors and the quality of life among the elderly during the COVID-19 pandemic at the Tresna Werdha Budi Mulia 3 Nursing Home. 
According to the Indonesian Ministry of Health (2018) (20), mental or psychological health is when the inner state is calm and peaceful. Some mental disorders include stress or depression, anxiety, and loneliness. Psychological factors are important factors for individuals to control all events experienced in their lives. Psychological changes stem from an awareness of the emergence of feelings of inferiority compared to younger, more robust, perceptive, and skilled people.

This study is in line with Ignasia et al. (2021) (19), where many respondents answered that they often have negative feelings such as feeling lonely, irritable, often hopeless, and anxious. And they also feel unable to concentrate when doing work. So it significantly affects the psychological domain so that the quality of life among the elderly becomes low.

Research by Anis Ika et al. (2012) (18) also found consistent results. There is an influence between psychological factors and the quality of life among the elderly with a close relationship of $\mathrm{r}=0.814$. Most of the TresnaWerdha Social Institution respondents have a history of low education. Anis Ika et al. (2012) (18) suggested that education can shape emotional intelligence. So that someone who has high emotional intelligence can control himself, manage emotions, motivate himself and direct himself to be more productive in doing various jobs. Someone with low emotional intelligence will quickly feel anxious, afraid to be alone, feel unloved, and prone to depression.

Based on several theories and research results above, it can be concluded that psychological health has a significant relationship with the quality of life among the elderly. Tranquility and peace of mind can make the elderly more meaningful in life. Vice versa, when the mind becomes chaotic, negative feelings and hopelessness will arise, affecting the quality of life. More than $50 \%$ of respondents answered that they feel lonely very often. This happened due to the decrease in family visits to the nursing home during the COVID-19 pandemic. In addition, they also often feel anxious about the COVID-19 pandemic, considering that COVID-19 is a reasonably dangerous disease.

\section{Relationship of Social Relationship Factors with Quality of Life among Elderly}

The analysis results between the factors of social relations with the quality of life among the elderly carried out with the Pearson ChiSquare test obtained $\mathrm{p}$-Value $=0.000$. This shows a significant relationship between social relations factors and the quality of life among the elderly during the COVID-19 Pandemic at Tresna Werdha Budi Mulia 3 Nursing Home.

According to Kwon et al. (2020) (21), the quality of life and social support have a positive correlation. Thus, the higher the social support, the better the quality of life. Strong peer support can improve psychological aspects of quality of life, reduce loneliness, and the risk of depression. Peer support can also motivate the elderly to keep the spirit in continuing life.

This study is in line with the research of Anis Ika et al. (2012) (18). His study showed an influence between social factors and the quality of life among the elderly, with the result pValue $=0.001$. The lack of harmonious social relations between the elderly at the Hargo Dadeli Wardha and the lack of activities for the elderly are the causes of the low social welfare there. Supposedly, the elderly should get a lot of activities to facilitate the relationship between the elderly and one another so that good social reactions are formed, ultimately affecting their quality of life.

In contrast, Ignasia et al. (2021) (19) found that the elderly in their research revealed that their social relationships were fine because they could still communicate with each other. The elderly can also carry out various activities outside, such as work, routinely carrying out religious movements, and various other activities.

The above differences may occur depending on the condition of the residence or the nursing home being occupied because every nursing home has its policy. In addition, the nature of the elderly is different because there are some elderly who prefer to be alone than having to gather or socialize with their friends.

As many as $61.4 \%$ of respondents had less active social relationship status during the COVID-19 pandemic. This condition declines from the period before the COVID-19 pandemic, where they could previously freely socialize in their environment but now have limitations in socializing. Like when dealing 
with friends around the nursing home, they have to wear masks when traveling out of their rooms or guesthouses and keep their distance more. In addition, relationships with family, because during the COVID-19 pandemic, the nursing home quite limited time for visits so that elderly families rarely came to visit. With this occurrence, the social level among the elderly decreases and can cause the quality of life among the elderly to decrease.

\section{Relationship of Environmental Factors with Quality of Life among Elderly}

The analysis results between environmental factors and the quality of life among the elderly were conducted with the Pearson Chi-Square test obtained $\mathrm{p}$-Value $=$ 0.000 . This shows a significant relationship between environmental factors and the quality of life among the elderly during the COVID-19 pandemic at the Tresna Werdha Budi Mulia 3 Social Institution.

Environmental factors are important factors that can affect the quality of life among the elderly. According to Sekarwiri (2018) (19), the dimensions of environmental factors include finance, freedom, physical security, and comfort, health and social care, the home environment, the opportunity to get new information and skills, participation in recreation, as well as the physical environment and transportation.

This study is in line with a previous study (18) that showed the influence or relationship between environmental factors and the quality of life among the elderly with a close relationship was $r=0.626$. The residence must create a calm, peaceful, and pleasant atmosphere for its residents so that residents can feel comfortable and at home to live in that place. Thus the elderly will be supported by their environment to achieve a high quality of life.

From several theories and research above, it can be concluded that the quality of life can also be influenced by the environmental situation in which it is occupied. $50 \%$ of respondents stated that they were dissatisfied with their environment. This relates to access to health services to meet financial needs. Since the COVID-19 pandemic, nursing home health services have declined, with most respondents saying that the availability of drugs at the nursing home clinic is incomplete. In addition, during the COVID-19 pandemic, it is also very rare for guests to visit, where the arrival of guests is one of the most awaited moments by respondents because they can get donations from guests who come. Some respondents gave answers that they were not satisfied with the health of their environment because they felt uncomfortable with their environment, considering that the Tresna Werdha Budi Mulia 3 Nursing Home also accommodates the elderly with mental disorders.

\section{Relationship of Spirituality Factors with Quality of Life among Elderly}

The analysis results carried out with the Pearson Chi-Square test obtained $\mathrm{p}$-Value $=$ 0.000 . This shows a significant relationship between spirituality factors and the quality of life among the elderly during the COVID-19 pandemic at the Tresna Werdha Budi Mulia 3 Nursing Home.

This research is also in line with Pramaysella et al. (2020) (22), who conducted a literature review study related to the relationship between spirituality and the quality of life among the elderly. The study showed an association between spirituality factors and the quality of life among the elderly. This is because the higher the level of spirituality possessed, the higher the quality of life owned by the elderly. Vice versa, when the spirituality level among the elderly is getting lower, the quality of life will be lower.

Spirituality is part of a different quality of life in self-capacity, consisting of personal values, standards, and beliefs. Spirituality can help individuals to find meaning and purpose in their lives. Spiritual changes in the elderly can be marked by the increasingly attached religious spirit and belief in life and patterns of thinking and acting for everyday life. Changes in spiritual needs are a parameter that can affect the quality of life among the elderly (22).

The above statement is also supported by Gallardo-Peralta's research (2017) (23), which shows that the spiritual dimension is significant for the quality of life dimension. When the elderly feel closer or more in harmony with God, the elderly can improve their adaptation to the changes inherent in old age. With this happening, the elderly will accept 
themselves more efficiently and improve their quality of life.

Based on the theory and research above, it can be concluded that spirituality is one of the essential factors in determining the quality of life among the elderly. Good spirituality can help improve the quality of life with a sense of security and mental peace when the elderly feel closer to their god. Most (58\%) respondents at the Tresna Werdha Budi Mulia 3 Nursing Home have a poor level of spirituality. This is caused by the declining level of health among the elderly, which can be a barrier to worship.

\section{ACKNOWLEDGEMENT}

The researcher thanks to the Dean of the Faculty of Health Sciences at the Nasional University, Dr. Retno Widowati, M.Sc. Thanks to Head of the Nursing Study Program, Faculty of Health Sciences, Nasional University, Mr. Ns. Dayan Hisni, S.Kep., MNS. Furthermore, thanks to Mrs. Ns. Diah Argarini, M.Kep., as supervisor 1 and Mrs. Ns. Susanti Widiastuti, M.Kep., as supervisor 2 has guided and provided input and provided full support in the preparation of this thesis. Researchers also thank the Tresna Werdha Budi Mulia 3 Nursing Home, especially grandmothers and grandfathers who have agreed to become respondents and the caretakers of the nursing home who have accompanied the research process. The researcher would also like to thank all family and friends and close friends who continually provide support and prayers to the researcher to complete this research correctly.

\section{REFERENCES}

(1) Worldometer. COVID-19 Corona Virus Pandemic [Internet]. 2021 [cited 2021 Jul 7]. Available from: https://www.worldometers.info/coron avirus/?zarsrc $=130$

(2) Satgas COVID-19. Peta Sebaran COVID19 [Internet]. 2020 [cited 2021 Jul 7]. Available from: https:/ / covid19.go.id/peta-sebaran

(3) Kemenkes Republik Indonesia. Hasil Riset Kesehatan Dasar Tahun 2018. Kementrian Kesehat RI. 2018;53(9):1689_
99.

(4) Satria RMA, Tutupoho RV, Chalidyanto D. Analisis Faktor Risiko Kematian dengan Penyakit Komorbid Covid-19. J Keperawatan Silampari. 2020;4(1):48-55.

(5) Komazawa O, Suriastini N, Mulyanto E, Wijayanti I, Maliki, Kharisma. Older People and COVID-19 in Indonesia. Indonesia: Survey Meter; 2021. p. 100.

(6) Guslinda, Nova Fridalni A, Minropa A. Faktor yang berhubungan dengan tingkat kecemasan lansia pada masa pandemi covid 19. 2020;12(4):1079-88.

(7) World Health Organization (WHO). WHOQOL: Measuring Quality of Life [Internet]. 2020 [cited 2021 July 7th]. Available from: https://www.who.int/tools/whoqol Destriande IM, Faridah I, Oktania K, Rahman S. Faktor Yang Mempengaruhi Kualitas Hidup Pada Lanjut Usia. J Psikol [Internet]. 2014;2(2002):483-90. Available from: www.jurnal.uwp.ac.id/fpsi/index.php/ psikowipa/article/download/41/15

(9) Van Leeuwen K, Van Loon M, Van Nes F, Bosmans J, De Vet H, Ket J. What does quality of life mean to older adults [Internet]. Plos One. 2020;14(3):1-39.

(10) Yanti DE, Keswara UR, Puteri RM. Perbedaan Kualitas Hidup Lansia Tinggal di Panti Tresna Werdha dengan Bersama Keluarga di Kecamatan Natar Kebupaten Lampung Selatan. J Dunia Kesmas. 2019;8:219-25.

(11) Dinsos Provinsi DKI Jakarta. Beranda Panti Sosial Budi Mulia 3 [Internet]. 2019 [cited 2021 Sep 17]. Available from: https:/ / dinsos.jakarta.go.id/struktur/u pt-panti-sosial/panti-sosial-tresnawerdha-budi-mulia-3

(12) Sugiyono. Metode Penelitian Pendidikan. 21st ed. Metode Penelitian Pendidikan. Bandung: Alfabeta; 2013. p. 122.

(13) Quality of Life Index Ferrans and Powers. Questionnaires and Scoring [Internet]. [cited 2021 Oct 25]. Available from:

http://qli.org.uic.edu/questionaires/qu estionnairehome.htm

(14) Skolnik R, Heung S. World Health Organization (WHO). The International 
Encyclopedia of Anthropology. 2018. p. 1-3.

(15) Haksara E, Rahmanti A. Inovasi Nursing Dialysis Development (Ndd) Terhadap Peningkatan Kualitas Hidup Pasien Dialisis. J Chem Inf Model. 2018;53(9):1689-99.

(16) Draft P. Ordinary Spiritual Experience. Arch Psychol Relig [Internet]. 2006;28(1):181-218. Available from: http:/ / www.dsescale.org/OrdSpirExp. pdf

(17) Ferretti F, Castanha AC, Padoan ER, Lutinski J, Silva MR da. Quality of life in the elderly with and without chronic pain. Brazilian J Pain. 2018;1(2):111-5.

(18) Rohmah AIN, Purwaningsih, Bariyah K. Quality of Life Elderly. 2012;120-32.

(19) Palit ID, Kandou GD, Kaunang WJP. Hubungan antara Aktivitas Fisik dengan Kualitas Hidup pada Lansia di Desa Salurang Kecamatan Tabukan Selatan Tengah Kabupaten Kepulauan Sangihe. J KESMAS. 2021;10(6):93-100.

(20) Kemenkes Republik Indonesia. Pentingnya Peran Masyarakat dan Keluarga dalam Meningkatkan Ku alitas Hidup Lansia [Internet]. 2013 [cited 2021 Jul 14]. Available from: sehatnegeriku.kemkes.go.id/baca/rilismedia/20130531/127972/ pentingnyaperan-masyarakat-dan-keluarga-dalammeningkatkan-kualitas-hidup-lansia/

(21) Kwon M, Kim SA, So WY. Factors influencing the quality of life of Korean older adults by economic status. Int J Environ Res Public Health. 2020;17(3):111.

(22) Pramaysella F. Hubungan Spiritualitas Dengan Kualitas Hidup Pada Lansia [Thesis]. Ungaran: Universitas Ngadi Waluyo Ungaran; 2020.

(23) Gallardo-Peralta LP. The relationship between religiosity/spirituality, social support, and quality of life among elderly Chilean people. Int Soc Work. 2017;60(6):1498-511. 